Original Article

\title{
THE ENHANCEMENT OF COLLAGEN SYNTHESIS PROCESS ON DIABETIC WOUND BY MERREMIA MAMMOSA (LOUR.) EXTRACT FRACTION
}

\author{
ANCAH CAESARINA NOVI MARCHIANTI ${ }^{1 *}$, MEGA CITRA PRAMESWARI ${ }^{2}$, ELLY NURUS SAKINAH $^{3}$, EVI UMAYAH $^{2}$ \\ ULFA $^{4}$
}

${ }^{1}$ Department of Public Health, Faculty of Medicine, University of Jember, Jalan Kalimantan No.37 Jember, Indonesia, ${ }^{2}$ Medical Education Program, Faculty of Medicine, University of Jember, Jalan Kalimantan No.37 Jember, Indonesia, ${ }^{3}$ Department of Pharmacology, Faculty of Medicine, University of Jember, Jalan Kalimantan No.37 Jember, Indonesia, ${ }^{4}$ Department of Microbiology and Pharmaceutical Biotechnology, Faculty of Pharmacy, University of Jember, Jalan Kalimantan No.37 Jember, Indonesia

Email: ancah@unej.ac.id

Received: 06 Oct 2018 Revised and Accepted: 20 Dec 2018

\section{ABSTRACT}

Objective: This research aimed to evaluate the effect of fractionation of Merremia mammosa Lour. (Mm (Lour.)) extract on diabetic wound healing by observing the collagen synthesis process and to search the most potent fraction.

Methods: Wistar rats were divided into five groups ( $\mathrm{n}=5$ ), i.e., K-(negative control), $\mathrm{K}+($ positive control), K1 (ethyl acetate fraction), $\mathrm{K} 2$ (water fraction), and $\mathrm{K} 3$ (n-hexane fraction). The $\mathrm{Mm}$ (Lour.) was extracted with ethanol 70\%, then fractionated by using three solvents which have different polarity. The rats were adapted in $7 \mathrm{~d}$, then induced into diabetic by streptozotocin dose $40 \mathrm{mg} / \mathrm{kg}$ body weight. The wound was made by Morton excision method. Treatment was given every two days and a skin biopsy was done on day 11 . Analysis of collagen density was done by photomicrograph of histopathology preparations in Masson's trichome stained by using trinocular microscope with 400x magnification in 6 fields of view, then processed by imageJ software and analyzed by appropriate statistic tool.

Results: The results of this research showed that fractionation of $M m$ (Lour.) extract significantly enhanced diabetic wound healing based on macroscopic (percentage of wound healing) and collagen density with p-value $<0.05$ when compared with negative control, especially the water fraction ( $p=0.000)$. The follow-up post hoc analysis showed that there was no significant $(p=0.989)$ or there was no meaningful difference in the group of water fraction when compared to positive control.

Conclusion: Water fraction is the extract fraction of $M m$ (Lour.) which has the most significant influence on diabetic wound healing showed by enhancement of collagen synthesis.

Keywords: Wound healing, Diabetic wound, Merremia mammosa Lour, Collagen density

(C) 2019 The Authors. Published by Innovare Academic Sciences Pvt Ltd. This is an open-access article under the CC BY license (http://creativecommons.org/licenses/by/4.0/) DOI: http://dx.doi.org/10.22159/ijpps.2019v11i2.30170

\section{INTRODUCTION}

Diabetes Mellitus (DM) is a chronic metabolic disease caused by the insufficient production of insulin in the pancreas or the inability of the body to effectively use insulin produced. According to the International Diabetes Federation (IDF) [1], there were 382 million people living with DM in the world by 2013 and it is estimated that this number will increase to 592 million people by 2035 . As many as $25 \%$ of DM patients suffer from diabetic wounds and $85 \%$ of them experienced amputation [2]. Healing of diabetes wounds takes longer than normal wounds due to the disruption of the entire wound healing process. Therefore, proper treatment is needed. Treatment of diabetic foot commonly relies on gentamicin topical antibiotics. However, gentamicin causes side effects which can cause skin irritation, redness, allergies, and edema $[3,4]$.

Merremia mammosa (Lour.) (Mm (Lour.)) contains tannin (as antibacterial) and flavonoids (as an anti-inflammatory and antioxidant) which can inhibit bacterial growth, trigger macrophages to produce growth factors, neutralize free radicals, accelerate the inflammatory phase, trigger cell proliferation, and increase collagen synthesis which plays a role in wound closure [5, 6]. In our previous investigation [5-7] the extract used was ethanol. The investigation showed positive results on the percentage of healing and the number of fibroblasts in diabetic wounds. However, the extract did not only contain active ingredients but was still mixed with inactive components which can reduce the effectiveness of the extract. Therefore, it is necessary to do a separation to isolate multilevel compounds namely by fractionation [8].

Fractionation of $M m$ (Lour.) ethanol extract was conducted by using three different types of solvents based on polarity, namely water, ethyl acetate, and n-hexane by looking at the microscopic effect of the density of collagen formed. Collagen density examination was chosen because collagen plays an important role in the wound healing process, among others, the role in hemostasis, interaction with platelets, interaction with fibronectin, increasing cellular components, increasing growth factors, and promoting fibroplasias and epidermal proliferation. However, the formation of collagen tissue in the DM condition becomes obstructed which causes wound to be difficult to heal [9-11]. Therefore, based on this, in the present study, we examine the effect of extract fraction of $\mathrm{Mm}$ (Lour.) on diabetic wound healing by evaluating the collagen density.

\section{MATERIALS AND METHODS}

\section{Chemicals and reagents}

Chemicals i.e. ethanol, n-hexane, ethyl acetate, chloroform, ether, and reagents i.e. gallic acid and xylol were purchased from Merck [Indonesia]. Other chemicals such as ketamine $\mathrm{HCl}$ and xylazine were purchased from Guardian Pharmatama [Indonesia] and Interchemie Werken [imported from Holland]. From Sigma-Aldrich [Indonesia], Trichrome Stains, citrate buffer solution and Streptozotocin (STZ) were purchased. All other chemicals and reagents used for the analysis were analytical grade. Distilled water (aquadest) was used throughout the investigation.

\section{Animal mode}

This study used 25 male albino wistar rats in early adulthood weighing between 150-200 g and each was kept in an individual cage with a standard feed of ad libitum food and water. The rats were obtained from CV. Gamma Scientific Biolab, Malang, Indonesia. They were divided into 5 groups with 5 rats in each group $(n=5)$, i.e., 
$\mathrm{K}+$ (positive control group with gentamicin administration), $\mathrm{K}-$ (negative control group with aquadest administration), K1 (ethyl acetate fraction), K2 (water fraction), and K3 (n-hexane fraction). The rats were adapted for $7 \mathrm{~d}$, then induced into DM by injecting STZ in citrate buffer solution intraperitoneal each at 40 $\mathrm{mg} / \mathrm{kg}$ body weight (kgBW) dose and was given access to drink $10 \%$ dextrose for $24 \mathrm{~h}$ [12]. Rats with non-fasting blood glucoses less than $200 \mathrm{mg} / \mathrm{dL}$ on day 5 after STZ induction were excluded. Glucose examination was done once a week to ensure the diabetic condition.

\section{Wound excision}

Diabetic wounds were made by Morton excision techniques [13]. Rats were given a combination of ketamine at $50 \mathrm{mg} / \mathrm{KgBW}$ dose and xylazine at $10 \mathrm{ml} / \mathrm{KgBW}$ dose intramuscularly. Particular skin area was shaved and the skin of impressed area was excised to the full-thickness to obtain a rectangle wound area of about $25 \times 25 \mathrm{~mm}$. Measurement of the wound area to determine the percentage of wound healing [14] and administration of $25 \mathrm{mg}$ dose of each fractions were carried out every other day once a day after the wound was given.

This study followed the standard of ethics of Health Law research number 23/1992 and has obtained ethical approval number 1175/H25.1.11/KE/2017 from the Medical Faculty, University of Jember. The type of research used in this research was in vivo true experimental laboratories with the research design used was posttest only control group design.

\section{Formulation of the fraction of Mm (Lour.) extract}

The plant material, Mm (Lour.), was collected July 2017 from Klaten, Central Java Province, Indonesia. It is identified and deposited by
Herbarium Jemberiense, Biology Department, Mathematic and Natural Science Faculty, University of Jember (84/HB/7/2017). The viscous ethanol extract of $\mathrm{Mm}$ (Lour.) was fractionated with three different polarity types of solvents, i.e. water, ethyl acetate and nhexane [8]. 50 grams of the viscous extract was added to $100 \mathrm{ml}$ of water and stirred until homogeneous. This water fraction was separated subsequently in a successive partition using $\mathrm{n}$-hexane and ethyl acetate with a ratio of 2:3, repeated three times. The partition was evaporated with rotavapor to get $n$-hexane and ethyl acetate fraction. The water fraction was concentrated with freeze dryer until viscous fraction was obtained.

\section{Histopathology parameter}

The observation of collagen density was carried out on day 11 (n=5 per group) by taking pictures of histopathological preparations of Trichome Masson's staining with Olympus DP21 series microscope with 400x magnification each in 6 visual fields then processed by using image software (data represented in percentage as mean \pm SEM). Statistical tests were performed with the One Way Anova test or Kruskal Wallis test and were continued with Post Hoc Tukey or Mann-Withney [15, 16].

\section{RESULTS}

Based on fig. 1(A) and 2, there was an increase in the wound healing percentage, the largest percentage of healing occurred in K2 (the group of water fractions), followed by $\mathrm{K}+$ (gentamicin group). The lowest percentage of wound healing occurred in K-(aquadest group). Percentage difference of wound healing occurred from day 1 to day 11. The highest percentage of wound healing on day 1 was the K3 $(33.73 \pm 4.4 \%)$ and on day 3 was $\mathrm{K}+(50.46 \pm 6.3 \%)$. The top percentage of healing on day $5,7,9$, and 11 were $\mathrm{K} 2$ with the percentage of $68.73 \pm 2.7 \%, 81.31 \pm 1.8 \%, 90.08 \pm 2.3 \%$ and $93.4 \pm 1.3 \%$.

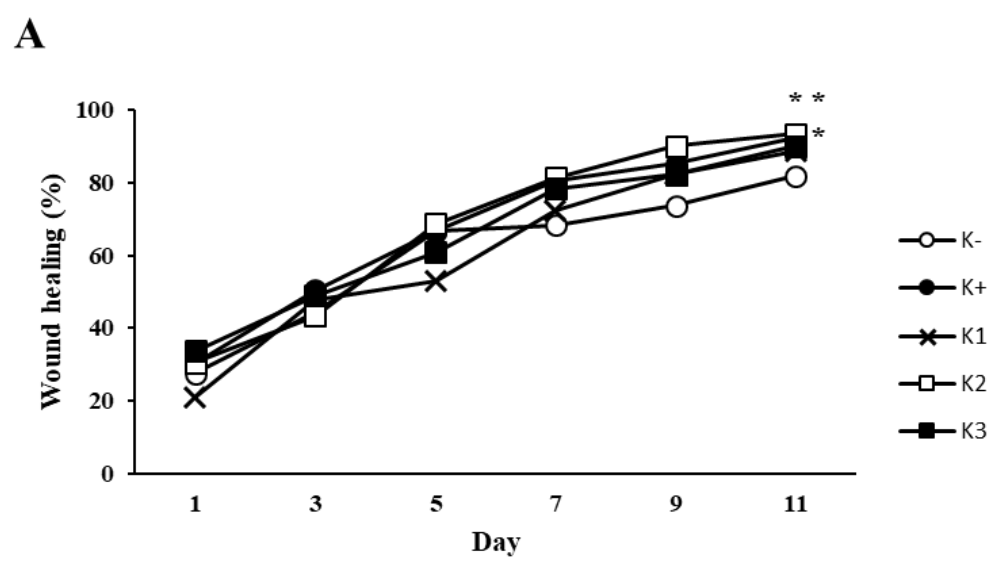

B

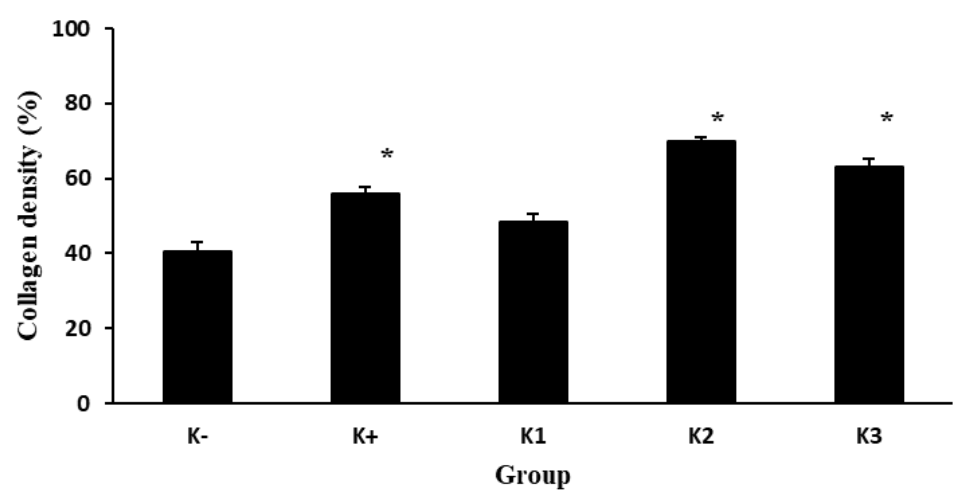

Fig. 1: The evaluation of diabetic wound healing by parameter of, (A): Wound healing percentage, (B): Collagen density, data represented in percentage as mean $\pm \operatorname{SEM}(n=5)$, *significant value at $P<0.05$ compared aquadest $(K-$ negative control group with aquadest administration, $\mathrm{K}+$ : positive control group with gentamicin administration, $\mathrm{K} 1$ : ethyl acetate fraction, $\mathrm{K2}$ : water fraction, $\mathrm{K} 3$ : $\mathrm{n}$-hexane fraction) 
The results of the wound healing percentage analysis were not significant on days 1, 3, 5 (One Way Anova test) and 7, 9 (Kruskal Wallis test). However, on the day 11 , there were significant results $(\mathrm{p}<0.05$; One Way Anova test) in the negative group compared with the positive groups, water fraction, and $n$-hexane fraction $(\mathrm{p}=0.008$; $\mathrm{p}=0.003$; $\mathrm{p}=0.014$; Post Hoc Turkey test), with each $\mathrm{n}=5$. Then followed by using post hoc, there was also no significant $(p>0.05)$ or there was no meaningful difference in the group of fractions when compared with the positive groups.

The order of collagen density average measured with Image software (fig. 1(B)) from low to high was K-(40.59 $\pm 2.4 \%)$, K1 $(48.21 \pm 2.4 \%), \quad \mathrm{K}+(55.94 \pm 1.7 \%), \quad \mathrm{K} 3 \quad(63.01 \pm 2.1 \%)$ and $\mathrm{K} 2$ $(70.02 \pm 1.0 \%)$. The collagen density analysis showed significant results $(p=0.000)$ when compared among groups by One Way Anova test. Tukey's post hoc test showed significant results $(\mathrm{p}=0.000$; $\mathrm{p}=0.000 ; \mathrm{p}=0.000$ ) of the group given gentamicin, water fraction, and n-hexane fraction compared to the group given aquadest, with each $n=5$. The group given the water fraction had no significant difference $(p=0.989)$ to the group that was given gentamicin. The water fraction group also showed no significant difference $(p=0.949)$ to the $n$-hexane fraction group. While the group given the ethyl acetate fraction showed a non-significant difference $(p=0.095)$ to the group given aquadest.

Fig. 3 shows collagen deposit (distinguished from others by blue color) observed in Masson's trichome staining. The collagen density was very low in the control group and ethyl acetate fraction group but the gentamicin group as control positive and other treated groups showed moderate and high collagen density. Loose collagenous matrix was found in the control group and ethyl acetate fraction group whereas in gentamicin group and other treated groups more compact and matured collagen deposit was observed. This result was similar to Kirubandanan et al. research observation of collagen deposit on day 12 of healing [17].
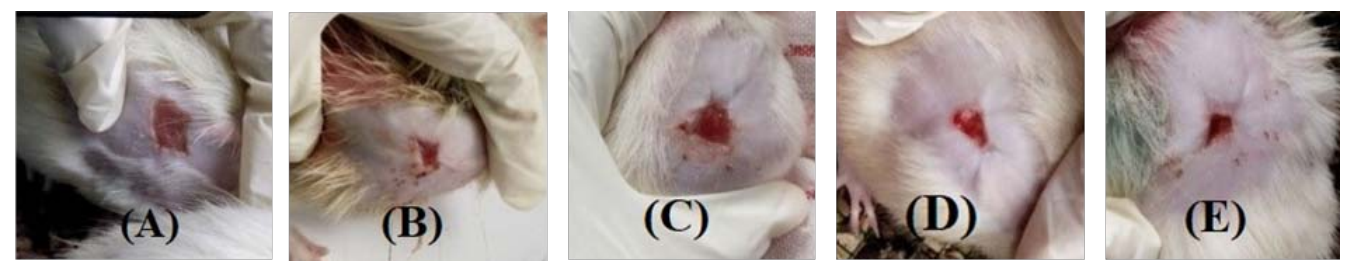

Fig. 2: Wound area on day 11 before termination, (A) Control; (B) Gentamicin; (C) Ethyl acetate fraction; (D) Water fraction; (E) n-hexane fraction
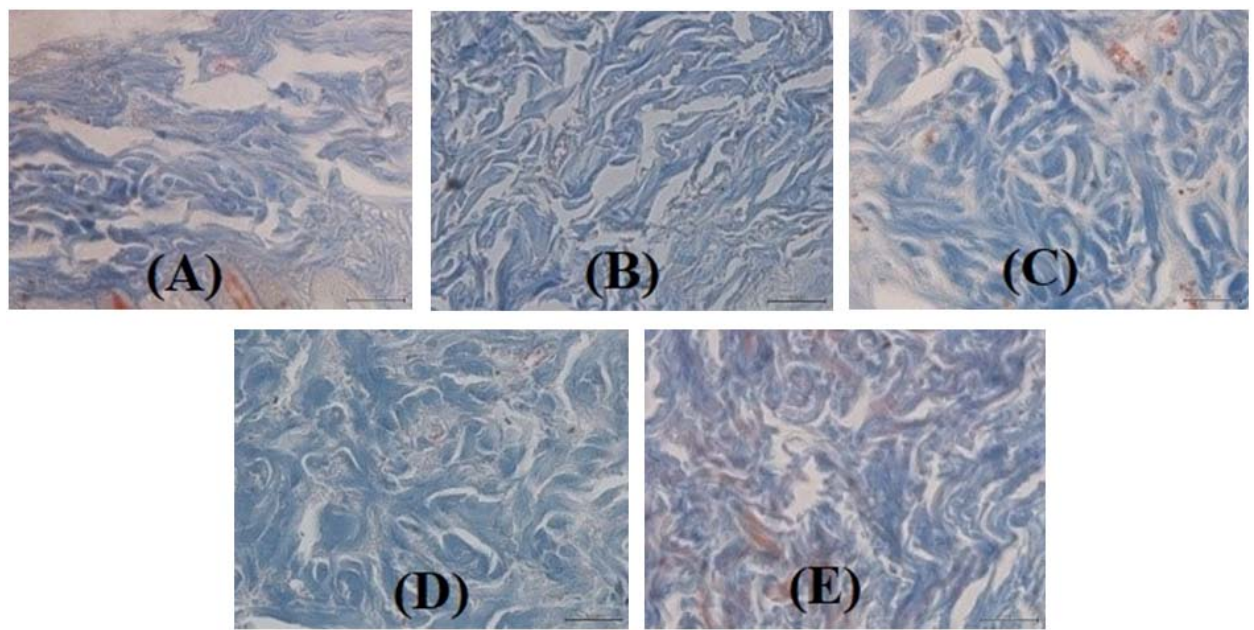

Fig. 3: Photomicrographs of rat skin tissues cross-section with Masson's trichome staining (collagen was distinguished from others by blue color) in 400x magnification, (A) Control; (B) Gentamicin; (C) Ethyl acetate fraction; (D) Water fraction; (E) n-Hexane Fraction

\section{DISCUSSION}

There were significant results in the percentage of day 11 wound healing and collagen density (fig. 1, 2 and 3). This showed that there was an effect of fractionation of $\mathrm{Mm}$ (Lour.) on the healing of diabetic wounds both macroscopically (wound area) and microscopic (collagen density). The administration of aquadest in the negative group showed the lowest percentage of wound healing and collagen density. This may occur because aquadest does not contain any other substances than H2O. Therefore, it only functioned to clean wounds from foreign objects attached to the wound [18]. Gentamicin administration had lower effect on collagen density than the water fraction and n-hexane fraction. This may occur because gentamicin contains the active ingredient of Gentamicin sulfate which was intended as an antibacterial. Whereas the pathophysiology of the occurrence of diabetic wounds is not only due to the occurrence of infection but also due to complications of neuropathy and blood vessel abnormalities in patients with DM. These complications cause disturbances in immune cell function, ineffective inflammatory response, endothelial cell dysfunction, neovascularization disorders, decreased collagen synthesis, worsening of epithelialization, decreased angiogenesis process and the inability of fibroblasts to form a maximum extracellular matrix [19].

This study showed that water fraction obtained the highest percentage of wound healing and collagen density compared to other treatment groups. There was a significant difference between the administration of water fraction and the administration of gentamicin or ethyl acetate fraction. This may occur because the water reaction has a higher antioxidant activity than the ethyl and nhexane fractions. The water fraction uses a polar solvent that can dissolve the flavonoids which are glycosidic and polyphenol groups and tannin substances which are higher than other fractions. Hence, due to the reason above, the administration of water fraction showed more optimal results in wound healing $[20,21]$. The use of water as a solvent has dissolved vitamin $\mathrm{C}$. Therefore, it contained vitamin $C$ while the other fractions did not. Vitamin $C$ is one of the enzyme co-factors in the process of forming protocollagen in the 
lysine and proline hydroxy stages. The protocol will become procollagen. Procollagen will become tropocollagen. Tropocollagen will divide into filaments and filament will become fibril. Fibrils will join to form fibers or collagen fibers. This was one of the causes that collagen density in the water fraction group showed a higher density than the other groups.

The result also showed that $n$-hexane fraction collagen density was lower than the water faction group. This may occur because the content of antioxidants and flavonoids in this group was less than in the type of solvent at other polarity levels [22, 23]. The group administered with ethyl acetate showed the lowest percentage of wound healing and collagen density among the fraction groups even when compared to the group administered with aquadest, it showed a non-significant difference. This is probably because ethyl acetate fraction has more toxic properties than the n-hexane and water fractions. Therefore, its pharmacological effects of wound healing were lower than the toxic effects produced [24, 25].

Although this study covered different groups of solvents, it did not include variations in doses of the fraction. Therefore, it did not measure the effective doses. In addition, this did not use carrier material as a mixture of the fractions. Therefore, further research shall include varying dosages to determine the effective dose and toxicity of the $\mathrm{Mm}$ (Lour.) and use carrier material as a mixture of fractions to make therapy to be more effective.

\section{CONCLUSION}

Based on the results obtained, it can be concluded that some fractionation of $\mathrm{Mm}$ (Lour.) extract had an effect on diabetic wound healing. Water fraction and n-hexane enhanced healing. Meanwhile, the ethyl acetate fraction showed no effect in the healing process. The most effective fraction, water fraction, is potential to be developed further as a topical drug.

\section{ACKNOWLEDGMENT}

This paper is based upon research supported by Ministry of Research, Technology and Higher Education of The Republic of Indonesia under Applied Product Research Funding

\section{AUTHORS CONTRIBUTIONS}

All the authors have contributed equally

\section{CONFLICTS OF INTERESTS}

All authors have none to declare

\section{REFERENCES}

1. International Diabetes Federation. IDF diabetes atlas. 6th ed. IDF; Brussels, Belgium; 2013. Available from: www.idf.org/ diabetesatlas. [Last accessed on 20 Aug 2018].

2. Ministry of Health of the Republic of Indonesia. Situation and analysis of diabetes. Data and information center of Ministry of Health of the Republic of Indonesia, Indonesia; 2014.

3. Chin LCH, Boulton AJM. The diabetic foot: epidemiology, risk factor, and standards of care in general surgery. Springer; 2009. p. 1867-76.

4. Nurlitasari N. Wound healing effect of perorally administration of combination sirih merah (Piper cf. fragile, Benth) leaves and pegagan (Centella asiatica, (L.) Urb) herbs infusions in the diabetic rat. Unpublished script. Universitas Indonesia, Depok, Indonesia; 2015.

5. Hidayat FK, Elfiah U, Sofiana KD. Comparison of the number of macrophage in full thickness wound incision between Merremia mammosa extract treatment and $\mathrm{NaCl}$ in male wistar rats. J Agromed Med Sci 2015;1:9-13.

6. Sofiana KD, Elfiah U, Ulfa EU. The effect of Merremia mammosa Lour. on wound healing of hyperglycemic male wistar rats. Unpublished articles. Fakultas Kedokteran Universitas Jember,
Jember, Indonesia; 2015. Available from: http://repository. unej.ac.id [Last accessed on 20 Aug 2018].

7. Julianto IGP. Effect of Merremia mammosa (lour) on wound healing process and blood sugar levels in hyperglycemic male wistar rats. Unpublished script. Fakultas Kedokteran Universitas Jember, Jember, Indonesia; 2015.

8. Mukhriani T. Extraction, separation of compounds and identification of active compounds. J Kesehatan 2014;7:361-7.

9. Novriansyah R. The difference of collagen density around wistar mice wound incision dressing with conventional gauze and occlusive hydrocolloid for 2 and $14 \mathrm{~d}$. Unpublished thesis. Universitas Diponegoro, Semarang, Indonesia; 2008.

10. Dewi AS. Antioxidant test of ethyl acetate fraction and water fraction of green tea ethanol extract through hydroxyl radical examination with deoxyribose method. Unpublished script. Universitas Sanata Dharma, Yogyakarta, Indonesia; 2007.

11. Sugara TH, Irawadi TT, Suprapto HH, Hanafi M. Anti-bacteria activity of ethyl acetate fraction of bandotan leaves (Agerantum conyzoides $L$ ). Jurnal Ilmiah Ibnu Sina 2016;1:88-96.

12. Damasceno DC, Netto AO, Iessi IL, Gallego FQ, Corvino SB, Dallaqua B, et al. Streptozotocin-induced diabetes models: pathophysiological mechanisms and fetal outcomes. Hindawi Publishing Corporation. BioMed Res Int 2014;1-11. http://dx.doi.org/10.1155/2014/819065

13. Morton JJ, Malone MH. Evaluation of vulnerary activity by an open wound procedure in rats. Arch Int Pharmacodyn Ther 1972;196:117-26.

14. Wathoni N, Hasanah AN, Mohammed AFA, Pratiwi ED, Mahmudah R. Accelerated wound healing ability of sacran hydrogel film by keratinocyte growth factor in alloxan-induced diabetic mice. Int J Appl Pharm 2018;10:57-61.

15. Badr G. Camel whey protein enhances diabetic wound healing in a streptozotocin-induced diabetic mouse model: the critical role of $\beta$-defensin-1,-2 and-3. Lipids Health Disease 2013;12:46.

16. Chen $\mathrm{Y}, \mathrm{Yu} \mathrm{Q}, \mathrm{Xu} \mathrm{C}$. A convenient method for quantifying collagen fibers in atherosclerotic lesions by imagej software. Int J Clin Exp Med 2017;10:14904-10.

17. Kirubandanan S, Bharathi R, Renganathan S. Histological and biochemical evaluation of wound regeneration potential of Terminalia chebula fruits. Asian J Pharm Clin Res 2016;9:228-33.

18. Amaliya S, Soemantri B, Utami YW. Effects of pegagan leaves (Centellaasiatica) extract in accelerating contaminated wound on Rattus novergicus wistar strain. Jurnal Ilmu Keperawatan 2013;1:19-25.

19. Waspadji S. Kaki Diabetes. Editor Setiati S, Alwi I, Sudoyo AW, MSK, B Setiyohadi, Syam AF. Buku Ajar Ilmu Penyakit Dalam. (Book of Internal Medicine). Edisi Empat. Jilid 2. Jakarta: Interna Publishing; 2015.

20. Prahesti NR, Suzery M, Cahyono B. The antioxidant activities, phenolic total, and cytotoxicity of extract and fractions of Aloe Vera Linn). Jurnal Sains Dan Matematika 2015;23:50-4.

21. Rahayu S, Kurniasih N, Amalia V. Ekstraksi dan identifikasi senyawa flavonoid dari limbah kulit bawang merah sebagai antioksidan alami. Al Kimiya 2015;2:1-8.

22. Pratiwi L, Fudholi A, Martien R, Pramono S. Ethanol extract, ethyl acetate extract, ethyl acetate fraction, and n-heksan fraction mangosteen peels (Garcinia mangostana L.) as the source of bioactive substance free-radical scavengers. J Pharm Sci Clin Res 2016;1:71-82.

23. Faisal AP, Azhari A. Identification of secondary metabolites and antioxidant activity of mojo leaves (Aegle Marmelos L.) against DPPH (1,1 Difenil-2-pikrilhidrazil) free radicals. Mahakam Med Laboratory Technol J 2017;11:27-36.

24. Pasilala FB, Daniel C, Saleh C. Toxicity test (brine shrimp lethality test) and antioxidant activity of sintrong leaves (Crassocephalum Crepidioides) 2,2-diphenyl-1-picrylhidrazil (DPPH) method. Jurnal Kimia Mulawarman 2016;14:13-4.

25. Tanaya V, Retnowati R, Suratmo S. Fraksi semi polar dari daun mangga kasturi (Semi polar fractions of Mangifera casturi Kosterm). Kimia Student J 2015;1:778-84. 